\title{
Imagining the Good Indigenous Citizen: Race War and the Pathology of Patriarchal White Sovereignty
}

\section{Aileen Moreton-Robinson}

In June 2007, the federal government sent military and police into Indigenous communities in the Northern Territory on the premise that the sexual abuse of children was rampant and a national crisis. This 'crisis' was constructed as something extraordinary and aberrant requiring new governmental measures. Agamben argues that this 'state of exception' is now the normal form of governance within democracies that 'establishes a hidden but fundamental relationship between law and the absence of law. It is a void, a blank and this empty space is constitutive of the legal system'. ${ }^{1}$ Guantanamo Bay has become the public face of the deployment of this state of exception, where law and lawlessness exist in dealing with detainees as a response to the events of 9/11, but it is not exceptional. Other detainees are held in various locations such as Camp Bucca, Abu Ghraib and Camp Cropper and in these camps the United States has determined its own rules, which are outside the law. In this sense, exceptionalism is not unified, but rather is a discursive formation that can only be partially known. ${ }^{2}$

While the state of exception thesis provides a way of explaining how sovereign states responded to terrorism through security measures, which requires disciplining detainees and citizens, the historical conditions of its possibility can be linked to colonisation. Australia, New Zealand, Canada and the United States have a long history of detaining Indigenous people, denying their rights and controlling behaviour 
through and beyond the law. From the late nineteenth century reserves, privately owned pastoral stations and missions were the places where the majority of Indigenous people in Australia lived under the control of white managers and missionaries appointed by government. Indigenous people, while living in poverty, were treated differently to white Australian citizens and were subject to 'special' laws, regulations and policies that were racist. Knowledge of the impoverished conditions under which Indigenous people lived was shared by those who controlled their lives. They acted disingenuously and their silence about Indigenous poverty operated repressively as 'an injunction to silence, an affirmation of nonexistence, and, by implication, an admission that there was nothing to say about such things, nothing to see, and nothing to know'. ${ }^{3}$ During the campaign for citizenship rights in the 1960s, Indigenous poverty was first brought into the public consciousness of white Australia through the advocacy of Indigenous people and their white supporters, televised and beamed into the living rooms of white middle-class Australia and represented within the print media. This occurred during the time that the white Australia policy was incrementally being phased out. White Australians voted in overwhelming numbers to endorse the 1967 Referendum believing they were casting a vote for Indigenous people to be included within the nation by being granted full citizenship rights. Within the white imaginary, citizenship represented equality and it was assumed that this status would enable Indigenous people to overcome their poverty and become the same as other Australians.

The 1967 Referendum did not confer on Indigenous people citizenship rights. Instead the constitution was changed to give the federal government the power to make laws on behalf of any race and Indigenous people could be counted in the census. ${ }^{4}$ The federal government of the day was well aware that these were the changes being made. The rhetoric of citizenship became a strategy by which Indigenous people could now come under federal government control instead of being primarily the responsibility of state governments. These changes to the constitution did not emerge publicly until the 1990 after academics revealed that Indigenous people 
were accorded civil, industrial, social and political rights incrementally from the 1960 s through the removal of explicitly racially discriminatory legislation and policies. Irrespective of this research the idea that Aborigines were granted citizenship rights in 1967 continues to circulate discursively. As a consequence, the lack of citizenship rights is no longer linked causally to Indigenous poverty within the white Australian imaginary; instead, social rights in the form of welfare payments are seen as having contributed to this outcome.

Since 1967 Indigenous people have continued to live in poverty irrespective of the level of economic prosperity of the nation or whether there are Labor or Liberal federal and state governments in power implementing their 'different' Indigenous affairs policies. There are still large gaps in outcomes between Indigenous people and other Australian citizens on all social indicators. Our life expectancy rates are seventeen years less than the rest of the population, our health is the worst in the country, we live in overcrowded houses, we have the highest unemployment rates, are over represented in the criminal justice system and our education outcomes are well below the Australian average. ${ }^{6}$ These differential outcomes and their history raise a question: do citizenship rights enable or constrain Indigenous people within society? In this essay I address this question by focusing on the Northern Territory Intervention. I argue that patriarchal white sovereignty as a regime of power deploys a discourse of pathology as a means to subjugate and discipline Indigenous people to be extra good citizens and that the tactics and strategies deployed within this race war reveal its own pathology. ${ }^{7}$

\section{Social contract and rights theory}

Social contract theorists, such as Locke and Rousseau, argued that the formation of the state was enabled by a contract between men to decide to live together, govern and make laws for such living. It is a contract that secures the right of the sovereign in the form of the state to govern and the right of citizens to partake in that governance and to live in society through the rights and responsibilities conferred on them. The problem with most social contract theories is that the moral egalitarianism that underpins them is predicated on the 
theory that the transition from a state of nature to civil society 'founds government on the popular consent of individuals taken as equals'. ${ }^{8}$ The white patriarchs who theorised about the social contract were primarily concerned with it being a means of agreement between white men to live together, make laws and govern incorporating white women into the polity as their subordinates through the marriage contract. ${ }^{9}$

In contrast, Michel Foucault offers a genealogy of rights from the seventeenth century to the present arguing that war has been central to the development of the judicial edifice of right in democratic as well as socialist countries. ${ }^{10} \mathrm{He}$ explains how in France the absolutist history of the divine right of kings was challenged by Boulainvilliers' production of a counter history, effectively introducing the new subject of rights into history. Refuting the myth of the inherited right to rule, Boulainvilliers' history of the nobility advanced the idea that because of their investments in participating in war they too had rights. Having become legitimate and normalised, Foucault argues, the nobility's assertion of rights was utilised by the commoners as an impetus to the French revolution; in this way a 'partisan and strategic' truth became a weapon of war. ${ }^{11}$ It is only by repressing the founding violence of sovereignty's emergence through war that equality can circulate as a truth constitutive of citizenship and its relationship to state sovereignty. While it is a truth that is challenged by theorists of citizenship within modernity, the right of state sovereignty functions discursively as not being born of conflict and war but rather of agreement between citizens. ${ }^{12}$

For Foucault, antagonisms, struggles and conflict are processes of war that should be analysed according to a grid of strategies and tactics because 'war' continues within government. The ensuing conflicts from the late eighteenth century between rulers and ruled increasingly involve a relation between a superior race and an inferior race. As Foucault argues, 'the State is no longer an instrument that one race uses against another: the State is, and must be, the protector of the integrity, the superiority, and the purity of the race'. ${ }^{13}$ 'Race' is defined by Foucault as a linguistic and religious marker that precedes the modern nation state, surfacing as a biological construct in the late eighteenth century just as regulatory 
mechanisms were developed to control populations. He describes this form of power as biopower, arguing that race became a means of regulating and defending society from itself. That is, race war continues in modernity in different forms, while sovereignty shifts from a concern with society defending itself from external attacks to focus on its internal enemies. What is important about Foucault's work is how race and war are tied to sovereign right. It offers us a different understanding of how colonisation operates through sovereign right as a race war whose power effect on the Indigenous population was one of 'to let live or die' and after occupation becomes one of 'to let live and to make live'. The origins of sovereignty in Australia are predicated on a myth of terra nullius (the imagination of an un-possessed continent) which functioned as a truth within a race war of coercion, murder and appropriation carried out by white men in the service of the British Crown. The military secured sovereignty on Australian soil in the name of the white King of England; in this way sovereignty was both gendered and racialised upon its assumption. Patriarchal white sovereignty is a regime of power that enabled the 'seizing, delimiting, and asserting control over a physical geographic area - of writing on the ground a new set of social and spatial relations' underpinned by the rule of death. ${ }^{14}$

As I have argued elsewhere, patriarchal white sovereignty in the Australian context derives from the illegal act of possession and is most acutely manifest in the state and its regulatory mechanisms such as the law. ${ }^{15}$ Therefore possession is tied to right and power in ways that are already racialised. Foucault argues that 'right' is both an instrument of, and vehicle for, the exercising of the multiplicity of dominations in society and the relations that enable their implementation. He argues that the system of right and the judicial field are enduring channels for relations of domination and the many forms of techniques of subjugation. For this reason 'right' should not be understood as the establishment of legitimacy but rather the methods by which subjugation is carried out. ${ }^{16}$ In this sense, citizenship rights are a means of race war that can be used strategically to circumscribe and enable the biopower of patriarchal white sovereignty. 


\section{Rights and race war}

Disciplinary knowledges that developed and deployed 'race' as a biological concept in the eighteenth century in Australia did so through a prevailing racist discourse. Indigenous people were considered a primitive people: nomadic, sexually promiscuous, illogical, superstitious, irrational, emotive, deceitful, simple minded, violent and uncivilised. We were perceived as living in a state of nature that was in opposition to the discourse of white civility. This racist discourse enabled patriarchal white sovereignty to deny Indigenous people their sovereign rights while regulating and disciplining their behaviour through legislative and political mechanisms and physical and social measures. After the 1967 Referendum it became increasingly difficult to continue to deny citizenship rights to Indigenous people. 'Race' had become the means to let live and to make live. After World War II the allies agreed to a new international regulatory mechanism being established to preserve human rights and justice while upholding state sovereignty in their respective countries.

The United Nations was established in 1942 and member countries agreed to be bound to the Declaration of Human Rights in 1948. Two important covenants were also ratified in 1966 by the United Nations which gave all people the right to self-determination and by virtue of that right they were free to pursue their political, cultural, social and economic rights within society. These covenants supplied moral and political strategies for the emergence of decolonisation and civil rights movements which soon spread globally. In Foucaultian terms, this represents a phase of war whereby the antagonisms, confrontations and struggles of the 1960 s became represented strategically and tactically through a discourse of Indigenous rights in the 1970s. In Australia the effects were the advocacy of civil, women's, gay and Indigenous rights claims of subjects within its borders. The White Australia Policy was formally abolished in 1972, while discriminatory legislation specifically designed for Indigenous people was revoked and new laws were enacted in 1975 to protect against racial and gender discrimination. An Indigenous land rights discourse, encompassing Indigenous sovereignty claims, was placed on the public agenda. Just as human rights were becoming an 
effective political weapon Australia strengthened its internal sovereignty by formally separating from British judicial review. The High Court of Australia became the final court of appeal, meaning the nation state's management of its citizens is no longer subject to an external sovereign's scrutiny.

\section{Race war and the discourse of Indigenous pathology}

Since the 1970 government policy has oscillated between self-management and self-determination. The former was concerned with administration and management of communities and organisations, while the latter 'implied control over policy and decision making, 'especially the determination of structures, processes and priorities'. ${ }^{17}$ While it is often argued that self-determination has been the dominant policy framework since the early 1970s, a closer analysis of government processes and practices would reveal that self-management has occupied centre stage, despite the establishment of the Aboriginal and Torres Strait Islander Commission (ATSIC) in 1989. ATSIC was represented to the world as the epitome of Indigenous self-determination by the Keating Labor government. However, regional councils did not have autonomous control over expenditure in their regions and ATSIC's budget, staff and policy areas were controlled and monitored in the same way as other government departments.

When the ATSIC commissioners did change the policy agenda, under the stewardship of Geoff Clarke, from one of self-determination involving decision making, to a selfdetermination model that advocated Indigenous rights, the newly elected Howard government, in concert with the media, represented ATSIC as mismanaged, misguided and corrupt. Howard deployed a discourse of pathology strategically to win electoral support aided by the mainstream media, representing its leaders as violent criminals and blaming ATSIC for the underperformance in policy and program areas, such as health and education, administered by mainstream departments. Howard had made an electoral promise that he would cut funding to Indigenous affairs, review ATSIC and amend native title laws to reduce the property rights Indigenous people had won in the High Court's Mabo decision. The pendulum, he argued, had swung too far in the direction 
of Indigenous people's rights. Through the use of the law the Howard government reduced and controlled the rights claims of Indigenous people, positioning us as having received more than our entitlements as citizens and not taking responsibility for our 'dysfunctional' behaviour. Rights of citizenship were deployed as weapons within the race war serviced by a discourse of Indigenous pathology. Within this discourse social problems are considered to be any forms of behaviour that violate the norms of white civility.

From 2000, Howard's Indigenous affairs policy agenda became concerned with 'practical reconciliation' involving mutual obligation contracts with Indigenous communities. The government's closure of ATSIC signalled the end of an Indigenous rights policy consistent with international covenants, and the beginning of a focus on 'practical measures' to alleviate Indigenous disadvantage. Significantly, the Howard government rejected the Aboriginal Reconciliation Council's Declaration Towards Reconciliation and any recommendation of a treaty. Mick Dodson, the former Indigenous Social Justice Commissioner, states that:

Howard responded with his own version of the Declaration. While there is considerable similarity between the two documents, there are more subtle differences in wording ... It refused to endorse the term 'selfdetermination', claiming that it implies the possibility of a separate Indigenous state or states. More significantly, the Howard government refused to support a formal apology to Indigenous people for past injustices, claiming that such an apology could imply that present generations are in some way responsible and accountable for the actions of earlier generations. ${ }^{18}$

Howard's tactics in the race war were to only recognise those rights that were available to other citizens, also making social rights of citizenship, such as the right to welfare support, the means of disciplining Indigenous subjects and containing their human right to be self determining. This regulation was rationalised within a neoliberal discourse which promotes formal equality of individuals through citizenship, allowing 
government to implement economic and social policies that reinforce structural inequalities between Indigenous people and the rest of Australian society.

The individualism of neoliberalism informs the discourse of pathology within the race war, enabling the impoverished conditions under which Indigenous people live to be rationalised as a product of dysfunctional cultural traditions and individual bad behaviour. In this context Indigenous pathology, not the strategies and tactics of patriarchal white sovereignty, is presented as inhibiting the realisation of the state's earlier policy of self-determination; because citizens have 'rights', the King no longer rules. Nonetheless, his 'Crown' remains intact as the holder of radical title to all land, meaning patriarchal white sovereignty can invade land occupied or owned by citizens when it wishes to do so. This was clear when the federal government sent the army and police into seventy-three Indigenous communities in the Northern Territory in $2007 .{ }^{19}$ The use of the term 'emergency response' by government signified that it was life or death situation requiring a response out of necessity; it was a state of exception. In effect, patriarchal white sovereign right was exercised, utilising the report as justification to further regulate and manage the subjugation of Indigenous communities, creating a new laboratory for an experiment in Indigenous civility.

The federal government passed five bills enabling the 'emergency response' and suspended the Racial Discrimination Act 1975 to protect itself from litigation. The media had prepared the white Australian imaginary by utilising a discourse of pathology, constantly reporting negative stories of Indigenous dysfunction, corruption, neglect and sexual abuse to elicit white virtue and possessive investments in citizenship. This discourse was deployed by Noel Pearson, an Aborigine from Cape York whose collusion with the media resulted in him being the first 'Aboriginal leader' to have a regular column in the Australian newspaper. In August 2000, he stated:

Our social life has declined even as our material circumstances have improved greatly since we gained citizenship. I have also come to the view that we suffered a particular 
social deterioration once we became dependent on passive welfare ... [This] has taken a decisive toll on our people, and the social problems which it has precipitated in our families and communities have had a cancerous effect on our relationships and values. Combined with our outrageous grog addiction and the large and growing drug problem amongst our youth, the effects of passive welfare have not yet steadied ... The violence in our society is of phenomenal proportion and of course there is intergenerational transmission of the debilitating effects of the social passivity which our passive economy has induced. (my emphasis) ${ }^{20}$

Pearson strategically uses citizenship rights to welfare as the enabler of Indigenous 'dysfunction' by arguing that these rights have given Indigenous people entitlements but no responsibilities. Between 2000 and 2004, Pearson produced twenty-five papers elaborating this thesis while also acknowledging that communities require service provision and resources to enable a change in behaviour. His argument is that citizenship rights should be tied to behavioural outcomes for Indigenous people as a means to let live and make live. Focusing on individualist explanations, Pearson promoted welfare reforms that mimicked the United States neoliberal conservative position of the early 1990s; these advocated 'reciprocal responsibilities' from adult welfare recipients to 'behave in socially approved ways' and required them to search for employment and to accept jobs when they are offered. ${ }^{21}$

Pearson's thesis that the right to welfare facilitates Indigenous addiction and dysfunction circulates as a truth in the race war, while masking the strategies of patriarchal white sovereignty to perpetuate Indigenous welfare dependency. Pearson indigenises welfare dependency, silencing talk about the behaviour of millions of non-Indigenous people who receive welfare in one form or another to enable them to live within society. In a 2007 response to Indigenous people advocating an Indigenous rights agenda, he outlined 'three problems' with their project: 
First, it is just not credible on too many questions. Ordinary Australians are simply not convinced that land rights and culture alone will solve social problems. Ordinary Australians can see through the fact social order is an urgent imperative ... The evidence of social and economic disrepair is too obvious for them to accept the old solutions. Those seeking indigenous rights must come up with more compelling justifications for the policies they propose. Second the advocacy must be more sophisticated and have more of an impact ... Third those concerned about rights must understand that most rights - the right to better health and education and safe and healthy children-cannot be delivered by rights alone. They require behavioural responsibility on behalf of our people ... The gap will not close unless we have a plan that is as forthright about these responsibilities as it is about rights. ${ }^{22}$

Pearson's pathologising works discursively. He positions Indigenous rights advocates as being unsophisticated, righteously impotent, incompetent and naïve. He appeals to and elicits the virtue of 'ordinary Australians' who are already assumed to be 'good citizens', strategically using the terms, as did Howard and Pauline Hanson, to seduce his white middle-class audience and affirm the characteristics of white civility. Pearson's explanation for the existence of poverty and inequality is the 'problematic' characteristics of Indigenous people, not patriarchal white sovereignty's right to disavow Indigenous sovereign resource rights. Indigenous people are perceived and talked about as the undeserving poor who lack effort, proper money management skills, a sense of morality and the ability to remain sober, the ability to resist drugs and a work ethic. Pearson has staked a possessive claim to patriarchal white sovereignty in his welfare reform agenda, which seeks to discipline and produce the good Indigenous citizen who is perceived as having no inherent sovereign right to their resources which were illegally appropriated by the Crown. The media and government have conferred on Pearson a leadership role, one which services the legitimacy of patriarchal white sovereignty by denying the effects of colonisation in producing economic dependency. This serves, in turn, to 
make invisible the ongoing race war against Indigenous people.

\section{Race war and tactics of intervention}

The print media's representation of Indigenous pathology in the race war was actively promoted by the national magazine the Bulletin in the late 1880s. Cartoons of drunken and destitute Aborigines were a regular feature over the subsequent century in its promotion of the white Australia policy. ${ }^{23} \mathrm{~A}$ National Inquiry into Racist Violence in 1991 concluded that the Australian media was responsible for the 'perpetuation and promotion of negative and racial stereotypes, a tendency towards conflictual and sensationalist reporting on race matters'. ${ }^{24}$ Over the next fifteen years it became the norm for negative stories about Indigenous people's 'demands' and 'dysfunctional behaviour' to circulate in the popular press, typified in May 2006 by a feature story on Indigenous sexual abuse in Central Australia broadcast on ABC's Lateline program. ${ }^{25}$ The main interview was with Dr Nanette Rogers, Crown Prosecutor in Alice Springs, who provided information on cases involving children as young as two years of age who had been raped. She explained that the silences around this sexual abuse could be attributed to entrenched violence, failure to take 'responsibility for their own actions' and the punitive nature of Indigenous society where reporting an incident could lead to 'harassment, intimidation and sometimes physical assault'. What Rogers did not disclose is the way in which silence operates as part of the cycle of sexual abuse in white communities, whether they are remote, rural and suburban; it is not openly discussed, easily reported and prosecuted. Child sexual abuse in white homes is dealt with by government as though it is something aberrant that requires intervention on an individual case by case model. There is no intervention into the whole community. The civil rights of perpetrators are respected. In contrast, child sexual abuse is treated as being normative within Indigenous communities, requiring everyone to be placed under surveillance, scrutinised and punished.

There was a flurry of media activity pathologising Indigenous communities after Rogers' interview. This was in 
stark contrast to the media's lack of response to Indigenous women's recommendations about the violence, alcohol, substance and sexual abuse in communities, which were made as early as 1980 . Recommendations from Aboriginal women concerning these issues and the need for increased service provision and resources were made at the ANZAAS 5oth conference in Adelaide in 1980, the Federation of Aboriginal Women's conference in Canberra in 1982, the National Aboriginal Women's Taskforce in 1986, the First Indigenous Women's Conference in Adelaide in 1989, the Remote Area Aboriginal and Torres Strait Islander Women's meeting in Laura in July 1991 and the ATSIC National Women's Conference in 1992 in Canberra. ${ }^{26}$ Governments and the media did not respond to any of these recommendations. As a white woman and a lawyer Rogers was already conferred with authority, legitimacy and virtue within the white imaginary. Her revelations confirmed Indigenous pathology and fed moral outrage within the race war. The decades of silence and inaction by government and media on these issues confirms that politics is race war by other means; during an election year the media and government strategically deployed the discourse of Indigenous pathology as a weapon by making child sexual abuse a central issue for voters.

In response to Rogers' national disclosure, the Northern Territory Labor government commissioned a board of inquiry into Indigenous child sexual abuse in August 2006, signalling that Labor, not the federal Coalition government, could stake a possessive claim to the morality and virtue of white civility. The inquiry's Little Children are Sacred report found that there was sufficient 'anecdotal and forensic and clinical information available to establish that there is a significant problem in Northern Territory communities in relation to the sexual abuse of children'. ${ }^{27}$ It acknowledged that alcohol and drug abuse, poverty, housing shortages, poor health and poor education were contributing factors to its prevalence, and recommended that the government consult with Indigenous communities on the implementation of their recommendations concerning service provision and resources. The majority of recommendations reveal the level and length of government neglect in service provision to its Indigenous 
citizens who have the highest levels of mortality and morbidity rates in the Western world. Within the race war, the exercising of patriarchal white sovereignty's right to let live or make live produces an early death for Indigenous people.

The recommendations in this report echo all the Aboriginal and Torres Strait Islander Social Justice Commissioner's reports from 1993 to 2007. In a 2005 speech, the chairman of the Australian Productivity Commission, Gary Banks, presented an overview of its Overcoming Indigenous Disadvantage report to government. It identified strategic areas for government action: early child development and growth (prenatal to age three); early school engagement and performance (pre-school to year three); positive childhood and transition to adulthood; substance use and misuse; functional and resilient families and communities; effective environmental health systems and economic participation and development. ${ }^{28}$ Similar recommendations were made in an earlier Senate report. ${ }^{29}$ But despite the advice and recommendations of its own mechanisms, the federal government failed to take responsibility for its policies. The exercise of sovereign right by patriarchal white sovereignty has continuously denied Indigenous sovereign rights by containing Indigenous people through social rights to welfare. Indigenous people have limited social capital and resources, independent of welfare, to engage in economic development.

Since colonisation began, patriarchal white sovereignty has deployed punitive action as a technique of subjugation in its relations with Indigenous people. And it has been cunning and deceitful in masking its subjugation. For example, in 1996 Prime Minister Howard removed \$470 million from ATSIC's budget and in 2007 \$39 million was cut from Abstudy, which had a direct impact on Indigenous peoples' participation in the education system. Between 2000 and 2007 the federal government increased its Indigenous budget to $\$ 3$ billion, however $\$ 360.45$ million of those funds which were identified for family violence programs, health, child care, business, education, housing and schooling was not spent by 2007 , and $\$ 136.216$ million was used as substitute funding on programs that benefit all Australians..$^{30} \mathrm{~A}$ similar picture has emerged from the Northern Territory, where only $\$ 43$ million of $\$ 177$ 
million allocated by the federal government in the areas of child and family services had been spent. Gerritsen states that federal funds are channelled into wealthy electorates for political purposes and that over 50 per cent of Indigenous funding 'ends up in white hands' ${ }^{3{ }^{1}}$ But the lack of resources and underspending of funds is not perceived to be linked to the impoverished conditions under which Indigenous people live. Instead, the discourse of pathology prevails as the government's explanation. 'Knowledge' about Indigenous pathology circulates as strategic truth in the race war to rationalise the continuing subjugation of the Indigenous population and encourage non-Indigenous investment in patriarchal white sovereignty.

In a speech to the National Press Club in July 2007, Mal Brough, Minister for Indigenous Affairs and Family and Community Services, took the opportunity to present the Howard government's welfare reform agenda..$^{32}$ Brough began his speech with a pledge of $\$ 1.8$ billion for older carers of disabled children, stating that the government 'has now said to older carers that we will ensure that you have a place and that you will have the services that you need as you grow older and frailer and that you have given your love and your life to your child who's disabled, we'll guarantee that'. Brough then made a discursive shift between the deserving poor, white citizens, and the undeserving poor, Indigenous people, who are rarely represented within the white national imaginary as carers or as disabled in spite of the well-known health statistics. When discussing Indigenous housing needs he stated that 'over years, ATSIC and successive federal governments have gifted over \$3 to \$4 billion worth of housing, lost control of it, don't know who's in the houses, whether they're appropriate people, whether rents are being paid, whether maintenance has been undertaken ... Put away the political correctness, let's stop that and let's do something that actually will provide more housing and better housing.' ${ }^{33}$ Brough imagined Indigenous people as inappropriate tenants, who behave irresponsibility by not valuing or maintaining their assets. The discourse of pathology is used to vilify Indigenous people while promising them more and better housing only if they behave like good white citizens. Throughout his speech Brough gave highly emotive 
individualised anecdotal evidence of the violence, substance and sexual abuse and neglect in Indigenous communities in order to substantiate the measures taken to intervene in the Northern Territory. Brough deployed the discourse of pathology to mask the government's neglect in service provision to Indigenous communities and justify increasing surveillance and subjugation.

The imposition of martial law and the emergency measures were outlined in a press release from Brough's office on 6 July 2007. The legislative package would allow the federal government to restrict alcohol, audit computers to detect pornographic material, lease Indigenous land and change land tenure to allow for private purchase, remove customary law as a mitigating factor for bail and sentencing; put in place business managers in remote communities; quarantine income support payments for basic necessities such as food, clothing and shelter; compulsory health checks for Indigenous children; change the permit system for access to Indigenous lands and abolish the Community Development Employment Program (CDEP). The law enables patriarchal white sovereignty's regulation of Indigenous behaviour through their social rights entitlements. Brough suggested that while the Little Children are Sacred report 'highlighted horrific abuse of children':

I was astounded that the report's authors provided no recommendations designed to immediately secure communities and protect children from abuse. The legislative measures being introduced tomorrow will achieve that. ${ }^{34}$

In order to shift responsibility for their poverty back onto Indigenous people, Brough negated the recommendations of the report, which clearly outlines the substantial neglect by government. Neglect, denial, blame, abdication of responsibility and violence are attributes of the dysfunctional behaviour of patriarchal white sovereignty which service Indigenous economic dependency and the negation of Indigenous sovereign rights.

In the conflict over the Intervention, the response to government from rights advocates was framed to deploy both 
citizenship and human rights as a strategic truth to make claims and repatriation against patriarchal white sovereignty. The Human Rights and Equal Opportunity Commission welcomed the government's announcements but argued that they should be delivered within a human rights framework. ${ }^{35}$ Approximately one hundred and seventy-five representatives of church, social service and civil rights organisations wrote an open letter to Brough, arguing that the services provided to other Australians are often not delivered to Indigenous communities and that 'in their present form the proposals miss the mark and are unlikely to be effective' due to 'an over-reliance on top-down and punitive measures'. ${ }^{36}$ Similarly, anthropologist Jon Altman argued that there is no evidence to show the relationship between child sexual abuse and changes to the permit system and compulsory acquisition of land: 'In particular both measures will lessen the property rights, and associated political and economic power, of an already marginalized Indigenous minority. ${ }^{3} 37$

Several months after the intervention, the Central Land Council consulted with traditional owners from across Central Australia. They found that overall most Indigenous people supported steps taken to address child abuse, housing shortages and increased policing but were opposed to 'five year lease, changes to the permit system, welfare reform measures' and changes to CDEP. ${ }^{38}$ The Aboriginal Rights Coalition's research into experiences and attitudes towards compulsory welfare management revealed that ' $85 \%$ of respondents do not like the intervention and see the overall changes as negative. $90 \%$ of respondents experience serious problems with income management. The changes have caused problems within families for $74 \%$ and made no change for $23 \%$.' 39 Rallies were held in June 2008, demanding 'the repeal of the NT Emergency Response legislation, the restoration of the Racial Discrimination Act 1975, increased funding for infrastructure and community controlled services and the implementation of the UN Declaration on the Rights of Indigenous Peoples'. However, patriarchal white sovereignty continued its welfare reforms regulating and defending society from itself and external sources by actively rejecting such human rights claims. The Australian government did 
not ratify the UN Declaration, which recognises Indigenous peoples' inherent sovereign rights to their lands, when it was passed by the UN General Assembly in 2007.

The election of the Rudd Labor Government in November 2007 did not signal a radical shift in policy. Rudd committed to Howard's measures but agreed not to preserve the CDEP and the permit system. The CDEP allows Indigenous people to work for their unemployment benefits in areas where virtually no labour markets exist. The 2006 Census revealed that of the 22,055 Indigenous people of working age in Northern Territory remote communities, 8 o per cent were unemployed and 20 per cent were on CDEP. $4^{\circ}$ The national statistics for unemployment are currently at 6 per cent. Keeping Indigenous people on CDEP hides the real levels of unemployment and exclusion from the economy. If the state of Indigenous economic disadvantage was reflected within the broader Australian citizenry there would be outrage and government would seek to intervene in the market to provide capitalists and workers with financial incentives to stimulate employment and economic development.

The government's agreement to retain the permit system was influenced by suggestions that it assisted in regulating the unwanted activities of outsiders and the exploitation of Indigenous artists. In their first budget the Rudd government committed a further $\$ 1.2$ billion to Indigenous expenditure over the next five years, most of which is committed to the Intervention. Only $\$ 554$ million is allocated to the majority of the Indigenous population who live in other states and territories but share the same socioeconomic position in Australian society. The Rudd government has called for a review of the Intervention measures and is seeking to establish an independent Indigenous body that will advise on Indigenous policy and programs but it will have no fiscal responsibility for them. The federal Department of Health's analysis of the mandatory child health checks revealed that out of the 7433 mandatory health checks of Indigenous children in the Northern Territory only thirty-nine were considered at risk of neglect or abuse with only four children identified as being sexually abused..$^{4}$ 


\section{Conclusion}

The discourse of pathology is a powerful weapon deployed by patriarchal white sovereignty to gain support from its white citizens for the exercising of its power. Race and rights are the means by which patriarchal white sovereignty exercises its power to let live and make live where the granting of life is conditional on the perceived appropriateness of the individual, the measure of which is the good white citizen. As a regime of power capillarising through rights and possession, it enables the law and government to intervene in the lives of Indigenous people to let them live and to make them live as welfare dependent citizens, not as property-owning subjects with sovereign resource rights. In this way citizenship rights are methods of subjugation because in their relations with sovereign right they can be both enabling and constraining.

In the race war with Indigenous people, patriarchal white sovereignty pathologises itself through the tactics and strategies it deploys in subjugation. Deceit, neglect, blame, abuse, violence and denial become tactics and strategies of war to subjugate the Indigenous enemies and their counter claims of sovereign rights, which are perceived to threaten the integrity of patriarchal white sovereignty's inherited right to rule. The pathological behaviour of patriarchal white sovereignty has been produced by the contradictions and imbalances in its fundamental constitution originating in Australia through theft and violence. The unfinished business of Indigenous sovereignty is refused by patriarchal white sovereignty because Indigenous entitlements to inherent resources would allow Indigenous people to engage in the economy on a different basis as self-determining property-owning subjects, which would alter the current state of exception. Within the race war Indigenous sovereign counter rights claims pose a threat to the possessiveness of patriarchal white sovereignty, requiring it to deploy a discourse of Indigenous pathology as a weapon to circulate a strategic truth: if Indigenous people behaved properly as good citizens then their poverty would disappear. 


\section{Notes}

1 Ulrich Raulff, 'Interview with Giorgio Agamben: Life, A Work of Art Without an Author: The State of Exception, the Administration of Disorder and Private Life', German Law Journal, vol. 5, no. 5, 2004, para 2.

2 Andrew W. Neal, 'Foucault in Guantanamo: Towards an Archaeology of the Exception', Security Dialogue, vol. 37, no. 1, March 2006, pp. 31-46.

3 Michel Foucault, The History of Sexuality: An Introduction, Vintage Books, New York, 1990, p. 4.

4 Bain Attwood and Andrew Markus, The 1967 Referendum, Aboriginal Studies Press, Canberra, 1997.

5 John Chesterman and Brian Galligan, Citizens Without Rights: Aborigines and Australian Citizenship, Cambridge University Press, Melbourne, 1997.

6 Tom Calma, Aboriginal and Torres Strait Islander Social Justice Commissioner, 'Achieving Aboriginal and Torres Strait Islander Health Equality within a Generation: A Human Rights Based Approach', presented at The Right to Health of Indigenous Australians seminar, University of Melbourne Law School, 16 March 2006.

7 Australia was acquired in the name of the King of England. As such, patriarchal white sovereignty is a regime of power that derives from the illegal act of possession and is most acutely manifested in the form of the Crown and the judiciary. The Crown holds exclusive possession of its territory, which is the very foundation of the nation-state. The nation-state in turn confers patriarchal white sovereignty on its citizens through what Carol Pateman argues is the sexual contract (The Sexual Contract, Stanford University Press, Stanford, 1988). However, not all citizens benefit from or exercise patriarchal white sovereignty equally. Race, class, gender, sexuality and ableness are markers that circumscribe the performance of patriarchal white sovereignty by citizens within Australian society.

8 Charles W. Mills, The Racial Contract, Cornell University Press, Ithaca, New York, 1997, p. 3 .

9 Pateman.

10 Michel Foucault, Society Must Be Defended, Penguin Books, London, 2003.

11 Ibid., p. 57.

12 Bart van Steenbergen (ed.), The Condition of Citizenship, Sage Publications, London, 1994.

13 Foucault, Society Must Be Defended, p. 81.

14 Achille Mbembe, 'Necropolitics', Public Culture, vol. 15, no. 1, 2003, pp. 25-6.

15 Aileen Moreton-Robinson, 'The Possessive Logic of Patriarchal White Sovereignty: The High Court and the Yorta Yorta Decision', Borderlands ejournal, vol. 3 , no. 2 .

16 Foucault, Society Must Be Defended, p. 27.

17 House of Representatives Standing Committee on Aboriginal Affairs, 'Our Future, Our Selves: Aboriginal and Torres Strait Islander Community Control, Management and Resources', August, 1990.

18 Michael Dodson, 'Indigenous Australians', in Robert Manne (ed.), The Howard Years, Black Inc., Melbourne 2004, p. 135.

19 Rex Wild and Pat Anderson, Ampe Akelyernemane Meke Mekarle 'Little Children are Sacred': Report of the Northern Territory Board of Inquiry into the Protection of Aboriginal Children from Sexual Abuse (2007), Northern Territory Government, Darwin, 2007, pp. 22-7.

20 Noel Pearson, 'The Light on the Hill', Ben Chifley Memorial Lecture, Bathurst Panthers Leagues Club, 12 August 200o, p. 1.

William Julius Wilson, 'Citizenship and the Inner-City Ghetto Poor', in Bart van 
Steenbergen (ed.), The Condition of Citizenship, Sage, London, 1994, p. 53.

22 Noel Pearson, 'Hunt for the Radical Centre', Australian, 21 April 2007.

23 Michael Meadows, Voices in the Wilderness: Images of Aboriginal People in the Australian Media, Greenwood Press, Westport, 2001.

24 Human Rights and Equal Opportunity Commission, 'Racist Violence: Report of the National Inquiry into Racist Violence in Australia', Australian Government Publishing Service, Canberra, 1991, p. 3.

25 Tony Jones, interview with Nanette Rogers, 'Crown Prosecutor Speaks Out About Abuse in Central Australia', Lateline, ABC Television, 15 May 2006, transcript available at http://www.abc.net.au/lateline/content/2006/s1639127.htm.

26 Aileen Moreton-Robinson, Talkin' Up to the White Woman: Indigenous Women and Feminism, PhD thesis, Griffith University, 1998, pp. 272-5.

27 Wild and Anderson, p. 8.

28 Gary Banks, 'Indigenous Disadvantage: Are We Making Progress?', 2005, p. 5, http://www.pc.gov.au/data/assets/pdf_file/0005/7655/cs20050921.pdf.

29 Nick Bolkus, 'Reconciliation: Off Track', Senate Legal and Constitutional References Committee, Canberra, October 2003, http://www.aph.gov.au/senate/ committee/legcon_ctte/reconciliation/report/report.pdf.

30 Joel Gibson and Debra Jopson, 'Black Dollars go Everywhere but to Blacks', Sydney Morning Herald, 21 August 2007.

31 Natasha Robinson, 'Northern Territory ‘Short-Changing' Indigenous Aid', Australian, 16 July 2008.

32 Mal Brough, 'Commonwealth's Intervention into Aboriginal Communities in the Northern Territory', National Press Club, ABC Television, 15 August 2007.

33 Brough, p. 4.

34 Mal Brough, 'Howard Government Getting On with the Job of Protecting Children in the Northern Territory', media release, 6 August 2007.

35 Human Rights and Equal Opportunity Commission, 'A Human Rights Based Approach is Vital to Address the Challenges in Indigenous Communities', media release, 26 June 2007.

36 Australian Council of Social Services, 'Open Letter to The Hon. Mal Brough MP', 26 June 2007, p. 2.

37 Jon Altman, 'The "National Emergency" and Land Rights Reform: Separating Fact from Fiction: An Assessment of the Proposed Amendments to the Aboriginal Land Rights (Northern Territory) Act 1979', Centre for Aboriginal Economic Policy Research, ANU, 7 August 2007, p. 2.

38 Central Land Council, 'From the Grassroots: Feedback from Traditional Landowners and Community Members on the Australian Government Intervention: An Initial Briefing Paper', Alice Springs, 19 December 2007, p. 2.

39 Aboriginal Rights Coalition, 'Data Shows Intervention is a Disaster: National Rallies Planned', 5 June 2008, p. 1.

40 Paul Toohey, 'Putting Paid to Perk for the Dole', Australian, 12 July 2008, p. 2.

41 Margaret Wenham, 'Indigenous Child Abuse in New Light', Courier-Mail, 25 May 2008. 